\title{
SEROTYPE-SPECIFIC AND HAEMADSORPTION PROTEIN OF THE AFRICAN SWINE FEVER VIRUS
}

\author{
Alexey D. Sereda, Anna S. Kazakova*, Ilnaz R. Imatdinov, Denis V. Kolbasov \\ Federal Research Center for Virology and Microbiology (FRCVM), Russian Federation \\ ${ }^{*}$ Corresponding author, E-mail: annakazakova85@gmail.com
}

\begin{abstract}
This review presents comparative results of simultaneously conducted studies on proteins responsible for the haemadsorption and serotype-specific properties of African swine fevervirus (ASFV).

An ASFV gene EP402R (or LMW8-DR) encoding protein CD2v homologous to murine, human or porcine T-cell adhesive receptor was found. The CD2v was shown to be directly involved into a haemadsorption process, and expressed in ASFV-infected cells as a glycoprotein with a molecular weight of approximately $105-110 \mathrm{kDa}$. In the presence of a glycosylation inhibitor, tunicamycin, its molecularweight is about $42 \mathrm{kDa}$.

In ASFV-infected cells labeled with ${ }^{3} \mathrm{H}$-glucosamine or ${ }^{14} \mathrm{C}$-sodium acetate, a virus-specific major glycoprotein with a molecular weight of 110-140 kDa (gp 110-140) was identified using radioimmunoprecipitation assay. Using ASFV reference strains belonging to seroimmunotypes I-IV and the corresponding antisera active in haemadsorption inhibition assay (HADIA), we determined that gp 110-140 defines the serotype specificity. Genotyping on the basis of the genetic locus encoding the CD2v and a C-type lectin proteinalso showed a concurrence with the grouping of ASFV isolates and strains based on their seroimmunotypes. Immunization of pigs with the gp 110-140 within liposomes, or a recombinant haemagglutinin (CD2v) protected 67 to $100 \%$ of animals from death due to their subsequent infection with homologous virulent ASFV strains.

Based on the physico-chemical and biological characteristics of the gp 110-140 and CD2v it is suggested that they are one and the same virus-specific glycoprotein crucial for induction of the immunological protection against ASF.
\end{abstract}

Key words: ASFV; seroimmunotypes; serotype; glycoproteins; gp 110-140; CD2v; protectivity

\section{Introduction}

African swine fever (ASF) is a contagious, septic viral disease of pigs characterized by fever, toxicosis, hemorrhages, and high mortality rate. The causative agent of the disease is a large DNA virus in the Asfarviridae family (1). Domestic and wild pigs (Sus scrofa) are all susceptible to ASF virus regardless of the breed or age. The disease can occur in various forms including fulminant, acute, subacute, chronic, and inapparent. The virus can be transmitted from sick animals and

Received:24 July 2017

Accepted for publication: 14 March 2018 virus-carriers by contact, by alimentary and transplacental routs, as well as by soft ticks of the genus Ornithodoros (2).

Cells infected with ASFV field isolates are able to adsorb swine erythrocytes (haemadsorption) on their surface (3), a property successfully exploited to differentiate the ASFV from other agents causing diseases with symptoms likely to be confused with those observed in ASF (4), to develop specific techniques for ASFV titration (5), to select attenuated variants in vitro (6).

The ability of serum from survivor-carriers to inhibit the haemadsorption reaction in the course of ASFV replication in pig bone marrow (PBM) cultures or swine leukocytes was used in studies 
on the antigenic diversity of the virus. Using haemadsorption inhibition assay (HADIA) and immunological bioassay, Malmquist (7) showed the antigenic diversity of ASFV isolates identified in Africa. Zucas et al. (8) concluded that two or more immunological types circulated in Africa, whereas in European countries and in Cuba, the isolates were antigenically identical. SanchezBotija and Ordas confirmed that the European isolates Italy-67, Salamanca and Portugal-60 differed from the African isolates (9). Based on differences determined by HADIA with antisera against some ASFV strains from Katanga, Madeira Island and Portugal (1957 and 1960), Vigario et al. (10) classified the available isolates into three antigenic groups (A, B and C) using Lisbon-57, Lisbon-60, Hinde-2, Rhodesia and Mozambique ASFV as the reference strains. Analysis of more than 100 virulent and attenuated strains provided the basis for ASFV seroimmunological classification (11-13).

ASFV strains are assigned to a respective group based on the data obtained in vivo (bioassay based on cross protection of pigs survived after their infection with a virulent strain) or in vitro (HADIA). The strains assigned to the same group using results of bioassay and HADIA were combined into nine separate seroimmunotypes with the respective reference strains: I - Lisbon-57 (L-57), II - Congo-49 (C-49), III - Mozambique-78 (M-78), IV - France-32 (F-32), V - TSP-80, VI - TS-7, VII - Uganda, VIII - Rhodesia and Stavropol 01/08 (including other strains of genotype II currently circulating in Eastern Europe), and IX - Davis (14, 15).

Genotyping of ASFV isolates by partial sequencing of the $\mathrm{B} 646 \mathrm{~L}$ gene that encodes the major capsid protein p72 has identified 23 genotypes $(16,17)$. HADIA serology provides a measure of ASFV typing that, compared with p72 genotyping, better discriminates biologically pertinent phenotypes. Viruses belonging to one p72 genotype may be serotypically different. For example, ASFV isolates belonging to seroimmunotypes I, II, and IV were all clustered into genotype I. This indicates heterogeneity among ASFV strains isolated on the European continent (18).

This review presents comparative results of simultaneously conducted studies on proteins responsible for the haemadsorption and serotypespecific properties of ASFV.

\section{Haemadsorption protein CD2v}

The initial reports on the detection of these proteins were published in the 1990s. Furthermore, an ASFV gene EP402R (also known as LMW8-DR) encoding a polypeptide of 402 amino acids homologous to an adhesive receptor of the T-cells (CD2) of mice, humans and pigs was revealed $(19,20)$. The expected molecular weight of the non-glycosylated polypeptide was $45.3 \mathrm{kDa}$. Hydrophilicity profiling shows that this protein is a typical transmembrane protein consisting of four differentiated regions: a hydrophobic leading region at the $\mathrm{N}$ terminus of 20 amino acids; a hydrophilic extracellular region of 183 amino acids with 15-16 glycosylation sites; a transmembrane region of 25 amino acids; and a proline-rich cytoplasmic C-terminal region of 174 amino acids. The protein $\mathrm{CD} 2 \mathrm{v}$ was shown to be expressed in ASFV infected cells as a glycoprotein of approximately $105 \mathrm{kDa}$ (25). The extracellular region of the protein contains two Ig-like domains, whereas CD2 has three or four such domains (19-24). Deletion of the EP402R had no effect on the rate of virus replication in vitro, although the virus lost the ability to induce adsorption of pig erythrocytes on the surface of infected cells, indicating that the ASFV protein $\mathrm{CD} 2 \mathrm{v}$, encoded by EP402R, is associated with the phenomenon of haemadsorption.

\section{Serotype-specific glycoprotein gp 110-140}

Detection of the ASFV serotype-specific protein was reported in parallel with publications on the $\mathrm{CD} 2 \mathrm{v}$. Using radioimmunoprecipitation assay, a major virus-specific glycoprotein with a molecular weight of $110-140 \mathrm{kDa}$ was found as dumbbell-shaped band typical for highlyglycosylated proteins (26). For its detection two principal conditions were required: 1) use of the metabolically ${ }^{3} \mathrm{H}$-glucosamine-labelled proteins derived from lysates of PBM naturally susceptible A-cells infected with ASFV haemadsorbing strains as an antigen source; 2) use of the homologous antisera with high activity in HADIA as an antibody source. In the lysates of PBM A-cells infected with non-haemadsorbing ASFV strains or when using homologous antisera inactive in HADIA (e.g., antisera obtained from pigs inoculated with attenuated ASFV strains, inducing those with the 
atypical pattern of haemadsorption), gp 110-140 was not detected (Figure 1) (26).

The above conditions suggest that gp 110140 is a haemadsorption protein. The serological specificity of gp 110-140 has been determined. While using some homologous components in the radioimmunoprecipitation assay such as the lysate of PBM A-cells infected with seroimmunotype IV ASFV strain F-32 or serotype IV antiserum active in HADIA, the dumbbell-like bands of gp 110140 manifested as the major ones. In the assays using heterologous components such as lysates of PBM A-cells infected with seroimmunotype IV ASFV strain F-32 or serotype I antiserum active in HADIA, gp 110-140 was not detected in the fluorograms or manifested less intensively as compared to the results of the homologous assay (Figure 2).

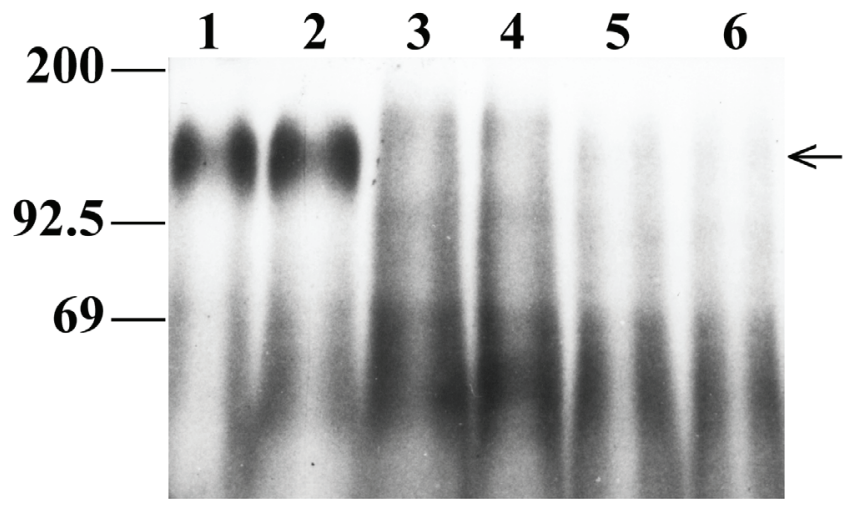

Figure 1: Immunoprecipitation of gp 110-140

A-cells of PBM were infected with ASF virus strains F-32 (tracks 1-4) or FNH (tracks 5 and 6) at the multiplicity of infection (MOI) of $5.0 \mathrm{HAU}_{50}$ or $50 \% \mathrm{TCID}_{50}$ per cell. One hour post infection, the growth medium was replaced by a glucose-free medium supplemented with $0.2 \mathrm{MBq} / \mathrm{ml} \mathrm{D}-\left(6-{ }^{3} \mathrm{H}_{1}\right)$ glucosamine hydrochloride. After 16 hours, the cells were harvested at a volume of $1 / 100$ of the original volume, pelleted and extracted in $1 \%$ Triton $\mathrm{X}-100$ in $0.02 \mathrm{M}$ Tris- $\mathrm{HCl}$ (pH 7.2). The immunoprecipitation was conducted using $1 \mathrm{~cm}^{3}$ of each cell extract and $0.05 \mathrm{~cm}^{3}$ of each serotype IV antiserum with activity in HADIA of 1:640 (tracks 1, 2, 5, and 6) or an inactive in HADIA antiserum from pigs inoculated with the attenuated strain FK-135 of seroimmunotype IV (tracks 3 and 4). The immune complexes were sorbed onto $0.1 \mathrm{~cm}^{3}$ Protein A-Sepharose ${ }^{\circledR}$ CL-4B (GE Healthcare). After washing, the sorbent was boiled in $0.1 \mathrm{~cm}^{3}$ of electrophoresis buffer. The molecular weight markers $(\mathrm{kDa})$ are shown on the left. The arrow on the right side indicates the gp 110-140 protein (26).
A method for quantitative assessment of serological relationship of haemabsorbing ASFV strains based on results obtained as qualitative assessment of gp 110-140 band intensity was developed. Results of radioimmunoprecipitation are to be recorded not through a visual examination of the fluorogram, but by the number of pulses per a minute using a $\beta$-counter. ${ }^{3} \mathrm{H}$-glucosaminelabelled gp 110-140 preparations, derived from haemadsorbing ASFV reference strains of seroimmunotypes I to IV purified with ionexchange chromatography on DEAE Sephacel, were used as antigens for the quantitative version of the radioimmunoprecipitation procedure. Reference antisera against ASFV serotypes I to IV (activity in HADIA 1: 320-1:640) were used as an antibody source (27-29). After washing the immune complexes precipitated on the

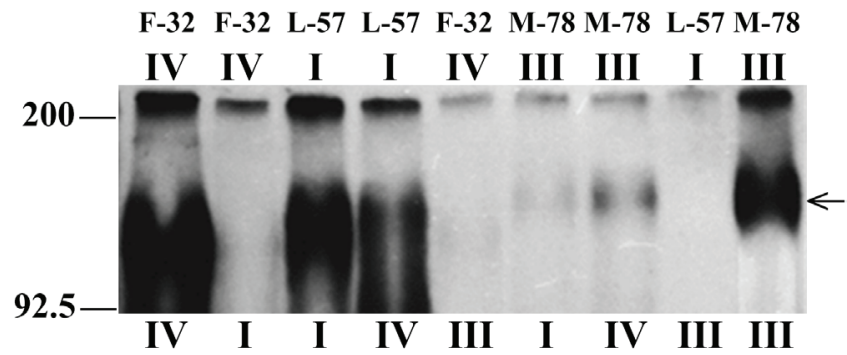

Figure 2: Serological specificity of gp 110-140

A-cells of PBM were infected with ASFV strains L-57, M-78 or F-32 at MOI of $5.0 \mathrm{HAU}_{50}$ per cell. One hour after inoculation, the growth medium was replaced by a glucose-free medium supplemented with $0.2 \mathrm{MBq} / \mathrm{cm}^{3}$ D- $\left(6-{ }^{3} \mathrm{H}_{1}\right)$ glucosamine hydrochloride. After 16 hours, the cells were harvested at a volume of $1 / 100$ of the original one and extracted in 1\% Triton X-100 in 0.02 M Tris$\mathrm{HCl}(\mathrm{pH}$ 7.2). The immunoprecipitation was conducted using $1 \mathrm{~cm}^{3}$ of cells extracts and $0.05 \mathrm{~cm}^{3}$ of antiserum of serotypes I, III or IV with activity in HADIA of 1:320 to $1: 640$. The immune complexes were sorbed onto $0.1 \mathrm{~cm}^{3}$ of Protein A-Sepharose ${ }^{\circledR}$ CL-4B. After washing, the sorbent was boiled in $0.1 \mathrm{~cm}^{3}$ buffer for electrophoresis. The virus strain and its seroimmunotype are indicated above, and the antiserum serotype is below. The molecular weight markers $(\mathrm{kDa})$ are shown on the left. The arrow on the right indicates the gp 110-140 protein (26). 
Protein A-Sepharose ${ }^{\circledR}$ CL-4B (GE Healthcare), equal volumes of the sorbent were boiled in electrophoresis buffer, and the radioactivity of the liquid phase was then determined using a $\beta$-counter. Since the incorporation of the ${ }^{3} \mathrm{H}$-glucosamine into gp 110-140 might depend on the quality of the cell culture, virus titre, and other features, the antigenic relationship was calculated by the relative value, representing percentage of specific binding. The radioactivity of the precipitate resulting from the specific binding of the serotype-specific antiserum and gp 110140 of the homologous reference ASFV strain was taken as $100 \%$. The percentage of specific binding obtained with the control sera of intact pigs was not greater than $3 \%$. The serological relationship of gp 110-140 with serotype-heterologous antisera varied from 20 to $45 \%$ (Table 1 ) which indicates that the gp 110-140 contains both homologous and heterologous epitopes.

Thus, the serotype specificity of gp 110140 was confirmed using two versions of radioimmunoprecipitation assay. Moreover, if on fluorograms visual differences in heterologous reactions were significant (Figure 2, tracks IV-IV and IV-I; I-III and III-III), the percentage of specific binding by the results of the scintillation counting was in the range of 20 to $45 \%$ (Table 2).
Furthermore, comparative genomics data indicate that the locus containing the adjacent genes of CD2v and C-type lectin protein is one of the most variable loci within ASFV genome (30). They share between 43 and $100 \%$ identity with the proteins encoded by the ORFs in other genomes making these amongst the most divergent orthologous clusters (31).

There are some ASF virus strains identical according to HADIA but different by data of immunoassay using animals. Thus, in pigs survived after inoculation with strain $\mathrm{F}-32$ and then infected with isolate Portugal-60 (P-60) acute ASF developed, although, based on the data of HADIA, strain P-60 belongs to serotype IV as well as F-32. Nevertheless, pigs survived after inoculation with strain P-60 survived the subsequent challenge with strain F-32. The assessment of the serological relationship between strain F-32/isolate P-60 gp 110-140 and antisera to seroimmunotypes I-IV as well as antisera to strain P-60 are shown in Table 2 (29). The antiserum to strain P-60 more effectively interacted with gp 110-140 from strains F-32 and P-60, and conversely the degree of antigenic relationship of strain P-60 gp 110-140 with antiserum to F-32 was only $69 \%$ which is consistent by the results of cross-infection of pigs.

Table 1: Antigenic relationship (\%) of gp 110-140 preparations of ASFV seroimmunotype I-IV reference strains to serotype I-IV antisera ( $\mathrm{n}=3$ to 5$)(28)$

\begin{tabular}{ccccc}
\hline \multirow{2}{*}{$\begin{array}{c}\text { gp 110-140, } \\
\text { (ASFV strain/Seroimmunotype) }\end{array}$} & Antisera (ASFV strain/Serotype) \\
\cline { 2 - 4 } & $100.0 \pm 0.0$ & $34.1 \pm 9.3$ & $20.2 \pm 8.7$ & $35.4 \pm 6.0$ \\
\hline L-57/I & $45.2 \pm 6.1$ & $100.0 \pm 0.0$ & $32.3 \pm 2.4$ & $30.3 \pm 4.2$ \\
\hline C-49/II & $22.3 \pm 7.4$ & $31.1 \pm 3.2$ & $100.0 \pm 0.0$ & $27.3 \pm 2.4$ \\
\hline M-78/III & $26.1 \pm 2.3$ & $27.3 \pm 7.2$ & $27.3 \pm 5.0$ & $100.0 \pm 0.0$ \\
\hline F-32/IV & & & & \\
\hline
\end{tabular}

Table 2: Antigenic relationship (\%) of gp 110-140 from strain F-32 or isolate P-60 to serotype I-IV antisera and isolate P-60 (29)

\begin{tabular}{cccccc}
\hline gp 110-140, & \multicolumn{5}{c}{ Antisera (ASFV strain or isolate/Serotype) } \\
\cline { 2 - 6 } $\begin{array}{c}\text { (ASFV strain or isolate/ } \\
\text { Seroimmunotype) }\end{array}$ & L-57/I & C-49/II & M-78/III & F-32/IV & P-60/IV \\
\hline F-32/IV & 31.3 & 27.8 & 27.4 & 100.0 & 120.0 \\
\hline P-60/ & 28.3 & 29.4 & 42.6 & 69.0 & 100.0 \\
\hline
\end{tabular}

* - the isolate is currently included into independent group (by seroimmunological classification), which includes isolates whose serotype obtained by HADIA did not correlate with the results of immunobiological test. 
Figure 3: Effect of glycosylation inhibitors on the molecular weight of gp 110-140 (fluorogram)

A-cells of PBM were infected with haemadsorbing ASFV strain F-32 at MOI 5.0 $\mathrm{HAU}_{50}$ per cell. One hour post infection, the growth medium was replaced by a glucosefree medium supplemented with $0.2 \mathrm{MBq} / \mathrm{cm}^{3} \mathrm{D}-\left(6-{ }^{3} \mathrm{H}_{1}\right)$ glucosamine hydrochloride and the glycosylation inhibitor (tracks 2, 3 and 4). After 16 hours, the cells were harvested at a volume of $1 / 100$ of the original one and extracted in $1 \%$ Triton $\mathrm{X}-100$ in $0.02 \mathrm{M}$ Tris- $\mathrm{HCl}$ (pH 7.2). The immunoprecipitation assay was carried out using $1 \mathrm{~cm}^{3}$ of each cell extract and $0.05 \mathrm{~cm}^{3}$ of serotype IV antiserum with activity in HADIA of $1: 640$. The immune complexes were sorbed onto $0.1 \mathrm{~cm}^{3}$ Protein A-Sepharose ${ }^{\circledR}$ CL-4B. After washing, the sorbent was boiled in $0.1 \mathrm{~cm}^{3}$ of electrophoresis buffer. The fluorogram: 1 - control, without inhibitor, 2 - with swainsonine $\left(1 \mu \mathrm{g} / \mathrm{cm}^{3}\right), 3$ - with tunicamycin $\left(1 \mu \mathrm{g} / \mathrm{cm}^{3}\right)$, 4 - with monensin $\left(0.5 \mu \mathrm{g} / \mathrm{cm}^{3}\right)$. The molecular weight markers $(\mathrm{kDa})$ are shown on the left. The arrows on the right side indicate the gp 110-140 protein (26).

\section{Physicochemical characteristics of gp 110- 140 and CD2v}

Also, some physical and chemical properties of gp 110-140 were tested. Thus, some differences in gp 110-140 average molecular weight among seroimmunotype I-IV ASFV reference strains were determined: for L-57 it was $126 \mathrm{kDa}$, for C-73-130 $\mathrm{kDa}$, for M-78 - $135 \mathrm{kDa}$, and for F-32 - 115-120 $\mathrm{kDa}(13,27)$. The above difference was assumed to be associated with the quantity and the size of the carbohydrate chains on the glycoprotein molecule. As determined using glycosylation inhibitors and glycoprotein trimming (tunicamycin, swainsonine, and monensin), oligosaccharides represent at least $50 \%$ of the gp 110-140 weight (Figure 3).

In the presence of swainsonine, the molecular weight of the serotype-specific glycoprotein decreased to $95 \mathrm{kDa}$ (Figure 3, track 2), and of monensin to $70 \mathrm{kDa}$ (Figure 3, track 4). Tunicamycin completely blocked N-glycosylation, and radiolabeled ${ }^{3} \mathrm{H}$-glucosamine was not incorporated into this molecule (Figure 3, track 3) (27). It is noteworthy that $\mathrm{CD} 2 \mathrm{v}$ is expressed as a glycoprotein of approximately $105-110 \mathrm{kDa}$ in ASFV infected cells, and in the presence of tynicamycin acting as a glycosylation inhibitor, the molecular weight of CD2v is about $42 \mathrm{kDa}(23,25)$. The presence of a formidable "carbohydrate cloud" on gp 110-140 could be a significant obstacle for

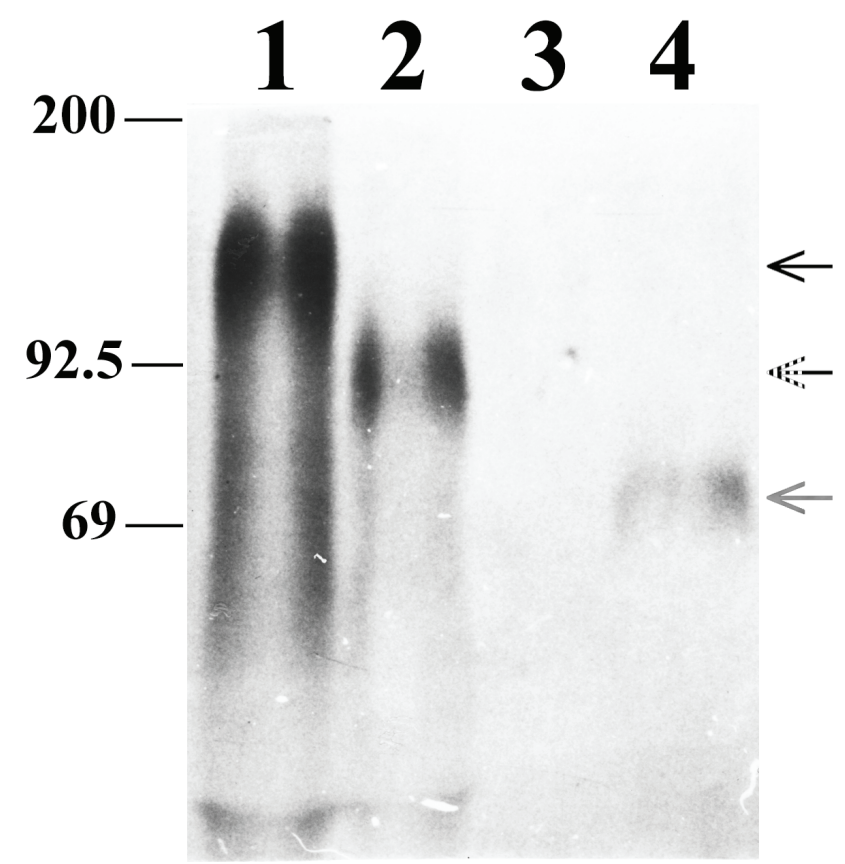

the immunorecognition of ASFV infected target cells by T-helper cells, cytotoxic T-lymphocytes and antibodies. Thus, the increased percentage of virus-specific cytotoxic T-lymphocyte-mediated lysis of PBM A-cells infected with haemadsorbing ASFV strains in the presence of the glycosylation inhibitor tunicamycin was evident (32). The gp 110-140 proved to be sensitive to protease $\mathrm{E}$ treatment and resistant to the treatment with trypsin, endoglycosidase $\mathrm{D}$, endoglycosidase $\mathrm{H}$ and/or a number of exoglycosidases (28). Furthermore, similar results were obtained when studying CD2v (25). The CD2vHA plasmid was transfected into Vero cells infected with the BA71V ASFV isolate. At $16 \mathrm{~h}$ post-transfection, CD2vHA was immunoprecipitated from cell extracts with anti-HA antisera, and the immunoprecipitates were digested with endo-H or endo-F. A proportion of the high molecular mass form of CD2vHA was resistant to digestion with endo- $\mathrm{H}$, but digestion with endo-F resulted in the disappearance of this form and appearance of a smaller band.

At a single-cycle infection, when the MOI of PBM A-cells infected with strain F-32 was 3 to $10 \mathrm{HAU}_{50}$ per cell, the gp 110-140 was detected starting from 6 to 8 hours post infection (p.i.) with maximum on the hour 10 to 12 p.i., whereas the budding of virions was seen 12 to 14 hours p.i. at the earliest (28). To follow CD2v localization during ASFV infection, CD2vHA was expressed 
in ASFV-infected Vero cells. The cells were fixed at $4,12,16$ and 20 hours p.i. and CD2vHA was detected with indirect immunofluorescence using a rat monoclonal antibody against the HA epitope and a fluorescent-labelled goat anti-rat secondary antibody. CD2v is expressed late in infection and therefore no expression could be detected at hour 4. From 12 hours p.i., a punctate pattern was detectable around the virus factories (25). The molecular weights as well as the similarity of the results with respect to the effect of the glycosylation inhibitors and endoglycosidases on gp 110-140 and CD2v, and also the dynamics of their detection in the infected cells, indicate that it is one and the same protein.

An isoelectric point in gp 110-140 was determined. To achieve the simultaneous radiolabelling of the proteins for amino acids and carbohydrate components, ${ }^{14} \mathrm{C}$-sodium acetate was used. The isoelectric focusing in granulated gel showed that gp $110-140$ had $\mathrm{pI}=4.3$ to 4.8 , which is the lowest pI level among all of the virusspecific proteins (Figure 4) (27).

Due to this property, a method for gp 110140 purification was developed based on the glycoprotein separation from other virus-specific proteins through preparative isoelectric focusing in a granulated gel Ultradex, and from cell proteins through subsequent affine chromatography on an immunosorbent prepared using immunoglobulins taken from homologous antisera.

\section{Protective properties of gp 110-140 and CD2v}

Inoculation of attenuated ASFV strains to pigs is known to protect animals from the disease and/or their death after their infection with some homologous virulent isolates or strains belonging to the same seroimmunological group (33-37).

Among all the known ASFV proteins, only gp 110-140 has a property of serotype specificity. Therefore, some experiments on pig immunization using preparations of purified gp 110-140 were performed. To enhance the immunogenicity, the gp 110-140 was incorporated into liposomes. As a result, the fourfold immunization with liposomeincorporated gp 110-140 was shown to protect two of the three challenged animals from death, but not from the disease (38). The pigs immunized with endoglycosidase F deglycosilated gp 110140 died due to challenge (39). These findings suggest gp 110-140 to be considered as one of the key components required for designing a new generation of protective preparations against ASFV using more effective approaches allowing protective epitopes to affect the porcine immune system.

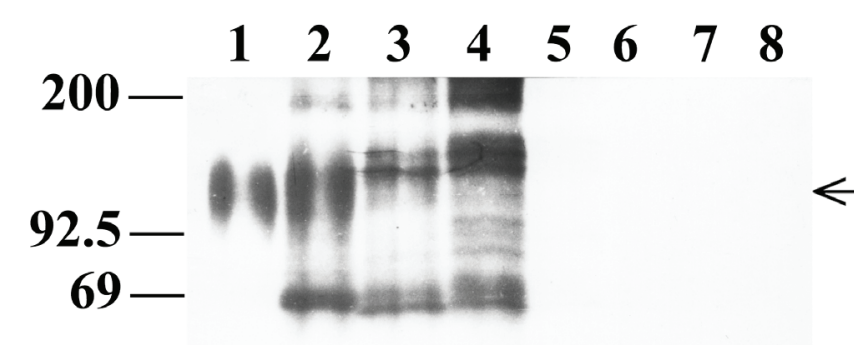

Figure 4: Electrophoregram of ASFV proteins separated with isoelectric focusing

PBM A-cells were infected with haemadsorbing ASFV strain F-32 at MOI of $5.0 \mathrm{HAU}_{50}$ per cell. One hour p.i., the medium was replaced and $0.1 \mathrm{MBq} / \mathrm{cm}^{3}$ $14^{\mathrm{C}}$-sodium acetate was added. After 16 hours, the cells were harvested at a volume of $1 / 100$ of the original one and extracted in 1\% Triton X-100 in 0.02 M Tris$\mathrm{HCl}$ ( $\mathrm{pH}$ 7.2). The isoelectric focusing of the extracted protein was carried out in granulated gel Ultradex with $1 \%$ solution of Servalites 4 to 9 . The solutions of each fraction were dialysed against $1 \mathrm{mM}$ Tris- $\mathrm{HCl}(\mathrm{pH} 7.2)$, and incubated with $0.05 \mathrm{~cm}^{3}$ of serotype IV antiserum (HADIA activity of 1:80 to 1:320). The immune complexes were adsorbed onto $0.1 \mathrm{~cm}^{3}$ Protein A-Sepharose ${ }^{\circledR} \mathrm{CL}-$ 4B. After washing, the sorbent was boiled in $0.1 \mathrm{~cm}^{3}$ buffer for electrophoresis. Tracks 1 to 8 show fractions with $\mathrm{pH} 3.53,4.27,4.72,5.19,5.83,6.45,7.25$, and 8.26, respectively. The molecular weight markers $(\mathrm{kDa})$ are shown on the left. The arrow on the right side indicates the gp 110-140 (27). 
The similar results were obtained with $\mathrm{CD} 2 \mathrm{v}$. A recombinant baculovirus containing $\mathrm{CD} 2 \mathrm{v}$ was constructed. The pigs immunized with the recombinant protein induced antibodies inhibiting haemadsorption and thus were protected from infection with a homologous virulent virus strain $(24,40)$. In our opinion, a relatively low molecular weight of the recombinant baculovirus $C D 2 v$ (75 $\mathrm{kDa})$ was due to incomplete glycosylation in the insect cells. Immunization of pigs with the recombinant DNA construction containing the genes of p30, p54 and the extracellular domain of $\mathrm{CD} 2 \mathrm{v}$ protected $67 \%$ of pigs infected with a virulent homologous ASFV strain against the disease $(41,42)$.

\section{Conclusions}

Antigenic heterogeneity of ASFV encouraged researchers to develop methods for its differentiation.

Using a collection of monoclonal antibodies that provided detection of 10 ASFV proteins, GarciaBarreno et al. (43) could reveal some binding properties of proteins of $23 \mathrm{ASFV}$ isolates from Africa, Europe and America, and classify them into six groups. Unfortunately, these findings have not been followed on.

Molecular and genetic methods opened up new opportunities. Mapping of the genome of ASFV isolates using restriction analysis confirmed their high level of heterogeneity. Using eight various restriction enzymes, Wesley and Tuthill (44) divided nine field ASFV isolates into four major groups: (i) the East African isolates Hinde1 and Uganda4, (ii) the Tengani isolate from Malawi, (iii) the Spencer isolate from South Africa, and (iv) the Lisbon/60, Madrid/75, Dominican Republic/78, Haiti/78 and Cameroon isolates. The genomes of the isolates from Cameroon, West \& Southwest Africa and Europe have been demonstrated to be similar to each other in many respects, whereas the genomes of the isolates from East and Southeast Africa are distinguished from those of the above isolates and also different from each other (45-48).

A method for ASFV isolate genotyping was developed in 2003 based on the partial sequencing of a 478-nucleotide fragment of the C-terminal region of the p72-encoding gene, which allowed classifying the examined isolates into 23 genogroups $(16,49,50)$. The further analysis of other variable regions of the genome of ASFV isolates provided dividing of the isolates which previously were classified into a single group based on the data obtained from p72-encoding gene sequencing, into 19 subgroups (51). The subsequent investigations led to the conclusion that care should be taken when constructing phylogenetic tree between ASFV isolates using a small number of genes (52).

Nevertheless, a relationship between the p72-based genotyping and the seroimmunotype classification was investigated. Great genotype and seroimmunotype diversity of ASFV was found in a relatively limited area in the SouthEast Africa. Significant was the fact that some ASFV genotypic clusters incorporate isolates belonging to different seroimmunotypes. Thus, ASFV isolates belonging to seroimmunotypes I, II and IV were all clustered only within genotype I. However, the ASFV isolate Spenser, that belongs to seroimmunotype II, was genotypically different from the genotype I as well as from all other 22 genotypes (18). Though the genotyping based on the sequence of the p72-encoding gene is a useful tool for phylogenetic analysis of the ASFV isolates, it is irrelevant to the biological features of the virus. Therefore, seroimmunotype classification based on the serological and protective characteristics is important for proper virus characterization and classification.

Following on from that consideration, it was established that genotyping on the basis of the genetic locus encoding the $\operatorname{CD} 2 \mathrm{v}$ and a C-type lectin protein is in agreement with the grouping of ASFV isolates and strains based on their seroimmunotypes (53). In other words, the researchers approached the unification of known ASFV classifications by genotype (using CD2v and C-type lectin protein) and ASFV immunological properties.

Thus, on the one hand, using the immunochemical methods, the gp 110-140 was identified as the haemadsorption-related serotype-specific protein, and, on the other hand, using the molecular biology methods, the CD2v was identified as the protein associated with the haemadsorbing characteristics. Taken together, this paper presents data demonstrating that the gp 110-140 and the CD2v are obviously one and the same glycoprotein, crucial for induction of the immunological protection against ASF. Taking into 
account the continuing studies on the ASFV CD2v protein properties and functional significance, the presented data on the serotype-specific gp 110140 contribute to an assessment of its significance in the creation of a unified classification of ASFV isolates, understanding of its role in the immune response, and in the development of the candidate vaccines.

\section{Acknowledgments}

This work was performed under a grant of the Russian Science Foundation (project No 1616-00090) 'Design of African swine fever virus candidate vaccine based on chimeric viruses'.

The authors express their gratitude to Prof. V.V. Makarov for assistance in carrying out this work.

\section{References}

1. Dixon LK, Alonso C, Escribano JM, et al. Asfarviridae. In: King AMQ, Adams MJ, Carstens EB, Lefkowitz EJ, eds. Virus taxonomy. Classification and nomenclature of viruses. Ninth Report of the International Committee on Taxonomy of Viruses (ICTV). Oxford: Elsevier, 2011: 153-62.

2. Sanchez-Vizcaino JM, Arias M. African swine fever virus. In: Zimmerman JJ, Karriker LA, Ramirez A, Schwartz KJ, Stevenson GW, eds. Diseases of swine. 10th ed, Ames: Wiley-Blackwell, 2012: 396-404.

3. Malmquist WA, Hay D. Hemadsorption and cytopathic effect produced by African swine fever virus in swine bone marrow and buffy coat cultures. Am J Vet Res 1960; 21: 104-8.

4. Hess WR, De Tray DE. The use of leukocyte cultures for diagnosing African swine fever (ASF). Bull Epizoot Dis Afr 1960; 8: 317-20.

5. Enjuanes L, Carrascosa AL, Moreno MA, Vinuela E. Titration of African swine fever (ASF) virus. J Gen Virol 1976; 32: 471-7.

6. Sereda AD, Balyshev VM, Morgunov YP, Kolbasov DV. Antigenic characteristics of African swine fever virus in artificial and natural mixed populations [in Russian]. Sel'skokhozyaistvennaya biologiya [Agric Biol] 2014; 4: 64-9.

7. Malmquist WA. Serologic and immunologic studies with African swine fever virus. Am J Vet Res 1963; 24: 450-9.

8. Lucas A, Haag J, Larenaudie B. La peste porcine africane. Collection monographique. Paris: Expansion scientifique française, 1967.

9. Sanchez-Botija C, Ordas A. Laboratory manual for diagnosis of african swine fever. Madrid: Instituto Nacional de Investigaciones Agrarias, 1977: 133-6.

10. Vigario JD, Terrinha AM, Bastos AL, Moura Nunes JF, Marques D, Silva JF. Serological behaviour of isolated African swine fever virus: brief report. Arch Gesamte Virusforsch 1970; 31: 387-9.

11. Vishnyakov IF, Mitin NI, Karpov G, Kurinnov VV, Yashin A. Differentiation of African and classical swine fever viruses [in Russian]. Veterinariya 1991; 4: 28-31.

12. Vishnyakov IF, Mitin NI, Petrov YI, et al. Seroimmunological classification of natural African swine fever virus isolates [in Russian]. Actual'nye voprosy veterinarnoi virusologii: mater. nauchn.prakt. konf. VNIIVViM "Klassicheskaya chuma svinei - neotlozhnye problemy, nauki I praktiki" (Current Problems of Veterinary Virology: Proc Sci Pract Conf VNIIVViM "Classical Swine Fever - Pressing Problems of Science and Practice"). Pokrov, 1995: 141-3.

13. Balyshev VM, Kalantaenko YF, Bolgova MV, Prudnikova EY. Seroimmunological affiliation of African swine fever virus isolated in the Russian Federation. Russ Agric Sci 2011; 37: 427-9.

14. Sereda AD, Balyshev VM. Antigenic diversity of African swine fever viruses [in Russian]. Vopr Virusol 2011; 56: 38-42.

15. Balyshev VM, Bolgova MV, Balysheva VI, Knyazeva NV, Zhivoderov SP. Preparation of standard haemadsorption-inhibiting reference sera against African swine fever virus [in Russian]. Voprosy normativno-pravovogo regulirovaniya $\mathrm{v}$ veterinarii 2015; 2: 23-5. https://rucont.ru/ efd/379353 (July 22, 2017).

16. Bastos ADS, Penrith ML, Cruciere C, et al. Genotyping field strains of African swine fever virus by partial p72 gene characterisation. Arch Virol 2003; 148: 693-706.

17. Achenbach JE, Gallardo C, Nieto-Pelegrin $\mathrm{E}$, et al. Identification of a new genotype of African swine fever virus in domestic pigs from Ethiopia. Transbound Emerg Dis 2017; 64(5): 1393-404.

18. Malogolovkin A, Burmakina G, Titov I, et al. Comparative analysis of African swine fever virus genotypes and serogroups. Emerg Infect Dis 2015; 21: 312-15.

19. Rodriguez JM, Yanez RJ, Almazan F, Vinuela E, Rodriguez JF. African swine fever virus en- 
codes a CD2 homolog responsible for the adhesion of erythrocytes to infected cells. J Virol 1993; 67: 5312-20.

20. Borca MV, Kutish GF, Afonso CL, et al. An African swine fever virus gene with similarity to the T-lymphocyte surface antigen CD2 mediates hemadsorption. Virology 1994; 199: 463-8.

21. Borca MV, Carrillo C, Zsak L, et al. Deletion of a CD2-like gene, 8-DR, from African swine fever virus affects viral infection in domestic swine. J Virol 1998; 72: 2881-9.

22. Peterson A, Seed B. Monoclonal-antibody and ligand-binding sites of the T-cell erythrocyte receptor (CD2). Nature 1987; 329: 842-6.

23. Goatley LC, Dixon LK. Processing and localisation of the African swine fever virus CD2v transmembrane protein. J Virol 2011; 85: 3294 305.

24. Ruiz-Gonzalvo F, Rodriguezv, Escribano JM. Functional and immunological properties of the baculovirus-expressed hemagglutinin of African swine fever virus. Virology 1996; 218: 285-9.

25. Kay-Jackson PC, Goatley LC, Cox L, et al. The $\mathrm{CD} 2 \mathrm{v}$ protein of African swine fever virus interacts with the actin-binding adaptor protein SH3P7. J Gen Virol 2004; 85: 119-30.

26. Sereda AD, Makarov VV. Identification of isolate-specific glycopolypeptide of African swine fever virus [in Russian]. Veterinariya 1992; 1: 22-4.

27. Sereda AD, Anokhina EG, Fugina LG, Makarov VV. Serological and physical-chemical properties of gp 110-140 of African swine fever virus [in Russian]. Veterinariya 1993; 1: 26-8.

28. Sereda AD, Anokhina EG, Makarov VV. Glycoproteins from the African swine fever virus [in Russian]. Vopr Virusol 1994; 39: 278-81.

29. Sereda AD. Quantitative determination of the antigenic relatedness of haemadsorbing ASFV strains [in Russian]. Veterinariya 2011; 6: 26-8.

30. Tulman ER, Delhon GA, Ku BK, Rock DL. African swine fever virus. Curr Top Microbiol Immunol 2009; 328: 43-87.

31. Chapman DA, Tcherepanov V, Upton C, Dixon LK. Comparison of the genome sequences of non-pathogenic and pathogenic African swine fever virus isolates. J Gen Virol 2008; 89: 397408.

32. Makarov VV, Sereda AD, Piria AA, Malakhova MS. The functional role of the glycosylation of viral components [in Russian]. Vopr Virusol 1992; 37: 267-70.

33. Mebus CA, Dardiri AH. Western hemi- sphere isolates of African swine fever virus: asymptomatic carriers and resistance to challenge inoculation. Am J Vet Res 1980; 41: 1867-9.

34. Ruiz-Gonzalvo F, Carnero E, Bruvel V. Immunological responses of pigs to partially attenuated African swine fever virus and their resistance to virulent homologous and heterologous viruses. In: Wilkinson PJ, eds. Proceedings of CEC/FAO Research Seminar, Sardinia. ASF, EUR 8466 EN. Luxembourg: Commission of the European Communities, 1983: 2066-216.

35. Hamdy FM, Dardiri AH. Clinic and immunologic responses of pigs to African swine virus isolated from the Western hemisphere. Am J Vet Res 1984; 45: 711-4.

36. Kolbasov DV, Balyshev VM, Sereda AD. Results of research works on the development of live vaccines against African swine fever [in Russian]. Veterinariya 2014; 8: 3-8.

37. Lacasta A, Monteagudo PL, Jiménez-Marín Á, et al. Live attenuated African swine fever viruses as ideal tools to dissect the mechanisms involved in viral pathogenesis and immune protection. Vet Res 2015; 46: 135 (1-16). https://veterinaryresearch.biomedcentral.com/track/pdf/10.1186/ s13567-015-0275-z (July 22, 2017)

38. Makarov VV, Perzashkevich VS, Sereda $\mathrm{AD}$, Vlasov NA, Kadetov VV. Immunological estimation algorithm of protective potential of viral components. [Study of preparations of purified inactivated African swine fever virus] [in Russian]. Vestnik Rossiiskoi Akademii Sel'skokhozyaistvennykh Nauk 1995; 6: 60-2.

39. Sereda AD. Immunogenic and protective characteristics of African swine fever virus glycoproteins [in Russian]. Actual'nye Voprosy Veterinarnoi Biologii 2013; 4: 31-5.

40. Ruiz-Gonzalvo F, Coll JM. Characterization of a soluble hemagglutinin induced in African swine fever virus-infected cells. Virology 1993; 196: 769-77.

41. Argilaguet JM, Perez-Martin E, Nofrarias $\mathrm{M}$, et al. DNA vaccination partially protects against African swine fever virus lethal challenge in the absence of antibodies. PLoS ONE 2012; 7(9): e40942 (1-11).

42. Argilaguet JM, Perez-Martin E, Lopez S, et al. BacMam immunization partially protects pigs against sublethal challenge with African swine fever virus. Antiviral Res 2013; 98: 61-5.

43. Garcia-Barreno B, Sanz A, Nogal ML, Vinuela E, Enjuanes L. Monoclonal antibodies of Afri- 
can swine fever virus: antigenic differences among field virus isolates and viruses passaged in cell culture. J Virol 1986; 58: 385-92.

44. Wesley RD, Tuthill AE. Genome relatedness among African swine fever field isolates by restriction endonuclease analysis. Prev Vet Med 1984; 2: 53-62.

45. Dixon LK, Wilkinson PJ. Genetic diversity of African swine fever virus isolates from soft ticks (Ornithodoros moubata) inhabiting burrows in Zambia. J Gen Virol 1988; 69: 2981-93.

46. Sumption KJ, Hutchings GH, Wilkinson PJ, Dixon LK. Variable regions on the genome of the Malawi isolate of African swine fever virus. J Gen Virol 1990; 71: 2331-40.

47. Ekue NF, Wilkinson PJ. Comparison of genomes of African swine fever virus isolates from Cameroon, other African countries and Europe. Rev Elev Med Vet Pays Trop 2000; 53: 229-36.

48. Selyaninov JO, Balyshev VM, Tsybanov SZ. African swine fever virus: physical mapping of the genome of the strains [in Russian]. Vestnik Ros- siiskoi Akademii Sel'skokhozyaistvennykh Nauk 2000; 5: 75-6.

49. Lubisi BA, Bastos AD, Dwarka RM, Vosloo W. Molecular epidemiology of African swine fever in East Africa. Arch Virol 2005; 150: 2439-52.

50. Boshoff CI, Bastos AD, Gerber LJ, Vosloo W. Genetic characterisation of African swine fever viruses from outbreaks in southern Africa (19731999). Vet Microbiol 2007; 121: 45-55.

51. Nix RJ, Gallardo C, Hutchings G, Blanco E, Dixon LK. Molecular epidemiology of African swine fever virus studied by analysis of four variable genome regions. Arch Virol 2006; 151: 2475-94.

52. Chapman DA, Darby AC, Da Silva M, Upton C, Radford AD, Dixon LK. Genomic analysis of highly virulent Georgia 2007/ 1 isolate of African swine fever virus. Emerg Infect Dis $2011 ; 17$ : 599-605.

53. Malogolovkin A, Burmakina G, Tulman MS, et al. African swine fever virus CD2v and C-type lectin gene loci mediate serological specificity. J Gen Virol 2015; 96: 866-73.

\title{
SEROTIPNO-SPECIFIČEN IN HEMADSORPCIJSKI PROTEIN VIRUSAAFRIŠKE PRAŠIČJE KUGE
}

\author{
A.D. Sereda, A.S. Kazakova, I.R. Imatdinov, D.V. Kolbasov
}

Povzetek: Pregledni članek predstavlja primerjavo rezultatov sočasno izvedenih raziskav o beljakovinah, ki so pomembne za hemadsorpcijo in serotipno specifične lastnosti virusa afriške prašičje kuge (ASFV; iz angl. african swine fever virus). Pri virusu ASFV je bil odkrit gen EP402R (imenovan tudi LMW8-DR), ki kodira beljakovino CD2v, ki je homologna glodavskemu, človeškemu in prašičjemu T-celičnemu adhezivnemu receptorju. Pokazalo se je, da je CD2v neposredno vpletena v proces hemadsorpcije in je izražena v celicah, okuženih z ASFV kot glikoprotein z molekulsko maso okrog 105-110 kDa. V prisotnosti zaviralca glikozilacije tunicamicina je njegova molekulska masa približno $42 \mathrm{kDa}$. V celicah, okuženih z ASFV, označenih s ${ }^{3} \mathrm{H}-g l u k o z a m i n o m ~ a l i$ ${ }^{14} \mathrm{C}$-natrijevim acetatom, je bil s testom radioimunoprecipitacije ugotovljen virusno specifični osrednji glikoprotein z molekulsko maso 110-140 kDa (gp 110-140). Z uporabo referenčnih sevov ASFV, ki pripadajo seroimunotipom I-IV, in ustreznim antiserumom, ki so bili aktivni pri preizkusu zaviranja hemadsorpcije (HADIA), smo ugotovili, da gp 110-140 določa specifičnost serotipa. Genotipizacija na osnovi genskega lokusa, ki kodira CD2v in C-tip lektinske beljakovine, je pokazala soizražanje s skupino izolatov in sevov ASFV na podlagi njihovih seroimunotipov. Imunizacija prašičev z gp 110-140 v liposomih ali z rekombinantnim hemaglutininom (CD2v) je zaščitila od 67 do 100 odstotkov živali pred smrtjo zaradi njihove naknadne okužbe z virulentnimi sevi ASFV. Na podlagi fizikalno-kemičnih in bioloških značilnosti beljakovin gp 110-140 in CD2v menimo, da gre za isti virusni glikoprotein, ki je ključnega pomena za vzpodbuditev imunološke zaščite pred ASF.

Ključne besede: ASFV; seroimunotipi; serotip; glikoproteini; gp 110-140; CD2v; zaščita 